\title{
KEDUDUKAN PERDAMAIAN SEBAGAI PENGHAPUS PEMIDANAAN GUNA MEWUJUDKAN KEADILAN DALAM PEMBARUAN HUKUM PIDANA
}

\author{
(Peace Agreement Position in Dismissing Penalty Imposition \\ to Achieve Justice in Criminal Law Reform) \\ Budi Suhariyanto \\ Pusat Penelitian dan Pengembangan Hukum dan Peradilan MA-RI \\ Jl. Jend. A. Yani Kav. 58 Cempaka Putih Timur Jakarta Pusat Indonesia \\ Email: penelitihukumma@gmail.com
}

Naskah diterima: 5 Maret 2017; revisi: 04 April 2017; disetujui: 17 April 2017

\begin{abstract}
Abstrak
Kitab Undang-Undang Hukum Pidana (KUHP) Indonesia yang berlaku saat ini merupakan warisan dari Pemerintah Kolonial Hindia Belanda (Wetboek van Srafrecht). Filsafat pemidanaan yang dianutnya kurang selaras dengan prinsip hidup masyarakat, dimana perdamaian tidak dapat dijadikan dasar untuk melepaskan terdakwa dari pemidanaan. Pada praktiknya, hakim melakukan terobosan hukum dengan memutuskan pelepasan tuntutan pemidanaan bagi perkara yang telah diadakan perdamaian. Tulisan ini bermaksud meneliti tentang kedudukan perdamaian dalam sistem pemidanaan yang dianut oleh hukum positif dan mengkaji putusan pengadilan yang melepaskan tuntutan pemidanaan berdasarkan perdamaian demi mewujudkan keadilan serta urgensi kedudukan perdamaian sebagai penghapus pemidanaan guna mewujudkan keadilan dalam pembaruan hukum pidana. Dengan menggunakan metode penelitian hukum normatif, diperoleh kesimpulan bahwa secara normatif, perdamaian antara pelaku dan korban tidak dapat menjadi alasan pelepasan tuntutan pemidanaan. Akan tetapi dalam praktiknya terdapat putusan pengadilan yang menjadikan bukti perdamaian sebagai alasan melepaskan tuntutan pemidanaan dan selanjutnya dijadikan sebagai yurisprudensi oleh Mahkamah Agung. Yurisprudensi ini perlu dijadikan rujukan untuk melakukan pengembalian filosofi pemidanaan nasional sesuai dengan nilai Pancasila yang mendasarkan perdamaian sebagai salah satu alasan penghapusan pemidanaan dalam Rancangan KUHP. Kata Kunci: pemidanaan, perdamaian, hukum pidana
\end{abstract}

\begin{abstract}
The current Indonesian Penal Code is the heritage of the Netherlands Indies Colonial Government (Wetboek van Strafrecht). The philosophy of the penalty imposition adopted by the code is less harmony with the society life principle, that the peace agreement between the parties can't be the basis to dismiss the accused from penalty imposition. In the practice, the judge makes law breakthrough by deciding a dismissal of all charges for cases that has been made peace. This paper intends to examine the position of peace agreement in the penalty imposition system that adopted by the positive law and reviews court judgement that dismissed all charges based on peace agreement for the sake of justice and the urgency of the peace agreement to eliminate penalty imposition in order to achieve justice in criminal law reform. By using the normative legal research method, this paper conclude that normatively, the peace between the defendant and the victim can't be a reason to dismiss all charges in criminal cases. However in the practice, there are court judgement that take the peace agreement as reason to dismiss all charges and then later is made as jurisprudence by the Supreme Court. This jurisprudence needs to be treated as a reference to restore the national philosophy of penalty imposition that fit the value of Pancasila where peace agreement is seen as a reason to eliminate the penalty imposition in the Indonesian Penal Code Draft.
\end{abstract}

Keywords: penalty imposition, peace agreement, criminal law 


\section{A. Pendahuluan}

Hukum pidana Indonesia yang berlaku saat ini merupakan peninggalan Belanda (Het Wetboek van Stafrecht) dengan didasarkan Undang-Undang Nomor 1 Tahun 1946, hukum pidana yang berlaku di Hindia Belanda menjadi hukum pidana Indonesia (KUHP). Hukum peninggalan Belanda ini sudah sangat tertinggal jauh dengan perkembangan masyarakat dan kebutuhan hukum pidana yang lebih baik. ${ }^{1}$ Khususnya yang berkaitan dengan pemidanaan, saat ini dianggap tidak memuaskan masyarakat. Hal ini telah memicu sejumlah pemikiran untuk melakukan upaya alternatif dalam menjawab persoalan-persoalan yang berkaitan dengan penanganan tindak pidana. Permasalahan seputar perkembangan sistem peradilan pidana yang ada sekarang menunjukkan bahwa sistem ini dianggap tidak lagi dapat memberikan perlindungan terhadap hak asasi manusia serta transparansi terhadap kepentingan umum. ${ }^{2}$

Sistem pemidanaannya yang bersifat individualistik dan formal prosedural telah mengabaikan realitas nilai perdamaian sehingga tidak dijadikan sebagai dasar penghapusan pemidanaan. Kepentingan Negara dalam penyelesaian perkara pidana sangat besar dan kuat untuk memidana kendati antara Pelaku dan Korban telah berdamai. Seolah-olah Negara akan bersalah jika Pelaku yang telah dimaafkan dan mengganti kerugian Korban dihapuskan pemidanaannya. KUHP kurang mengindahkan keberadaan dan penerapan filosofi musyawarah mufakat (berdasarkan
Pancasila) dalam perdamaian sebagai asas penyelesaian konflik antarwarga masyarakat, baik yang bersifat individual maupun ketertiban umum. Jika filosofi pemidanaan yang abai akan perdamaian dibiarkan berlarut-larut maka dikhawatirkan terjadi pergeseran budaya hukum dalam masyarakat. Budaya bangsa Indonesia yang awalnya adalah bangsa yang ramah, suka bersilaturahmi dan suka berdamai, sangat disayangkan bila bangsa ini telah menjadi bangsa yang emosional dan egois ${ }^{3}$ akibat hukum tidak menempatkan perdamaian sebagai penghapus pemidanaan.

Salah satu praktik yang terjadi, hakim melakukan terobosan hukum dengan memutuskan pelepasan tuntutan pemidanaan bagi perkara yang telah diadakan perdamaian. Sebagaimana Putusan Pengadilan Negeri Jakarta Utara-Timur Nomor 46/Pid/78/UT/ Wanita. Kasus ini menyangkut penyanderaan yang disertai dengan penghinaan dan kasus pengancaman yang dilakukan oleh Ny. Ellya Dado kepada Devy. Hal tersebut dilakukan Ny. Ellya Dado karena kecewa atau merasa tidak puas dengan sikap Devy yang telah merusak kendaraannya, tetapi tidak dilakukan perbaikan yang memuaskan. Akan tetapi, hal itu terjadi antara keluarga Ny. Ellya Dado dan Devy telah terjalin hubungan yang baik. dimana Devy adalah sahabat karib dari Soraya Dado, anak Ny. Ellya Dado. Keduanya adalah kawan baik, bekas satu sekolah dan hubungan itu tetap terbina sampai peristiwa itu terjadi. Karena kasus tersebut adalah masalah pidana, Jaksa

Agus Rusianto, Tindak Pidana \& Pertanggungjawaban Pidana: Tinjauan Kritis Melalui Konsistensi antara Asas, Teori, dan Penerapannya (Jakarta: Kencana, 2016), hlm. 1.

Eva Achjani Zulfa, Pergeseran Paradigma Pemidanaan (Bandung: Lubuk Agung, 2011), hlm. 2.

Hasballah Thaib, Perdamaian Adalah Panglima Dari Semua Hukum. Dalam Pendastaren Tarigan dan Arif (Ed). Spirit Hukum: Dedikasikan Untuk Purna Bakti 70 Tahun Prof. Hj. Rehgena Purba, S.H., M.H. (Jakarta: Rajawali Pers, 2012), hlm. 21. 
Penuntut Umum mengajukan tertuduh ke depan persidangan pengadilan. ${ }^{4}$

Jaksa Penuntut Umum dalam surat tuduhannya mengajukan tertuduh ke pengadilan untuk diperiksa secara singkat (summir) dengan dakwaan yang bersifat alternatif. Pada pokoknya isi singkat dakwaan tersebut adalah sebagai berikut: Pertama, dakwaan primair bahwa tersangka telah dengan sengaja dan melawan hukum telah merampas kemerdekaan orang, Devy, dengan melawan hak. dan karenanya perbuatan tersebut melanggar Pasal 333 KUH Pidana. Kedua, dakwaan subsidair, bahwa tersangka dengan maksud hendak menguntungkan diri sendiri atau orang lain dengan melawan hak, memaksa Devy dengan kekerasan atau ancaman kekerasan supaya Devy menyerahkan barang-barangnya. Perbuatan tersebut melanggar Pasal 368 ayat (1) KUH Pidana. Ketiga, dakwaan subsidair lagi: bahwa tersangka telah dengan sengaja dan melawan hukum telah menghina Devy dengan lisan. Perbuatan tersebut melanggar Pasal $315 \mathrm{KUH}$ Pidana. Kemudian, dalam surat penuntutannya, Jaksa Penuntut Umum pada pokoknya menuntut agar tertuduh dijatuhi hukuman penjara selama dua minggu dalam masa percobaan satu bulan dan mengembalikan barang bukti berupa gelang emas dan cincin emas pada saksi korban Devy dan membayar ongkos perkara karena melanggar Pasal 315 KUHP. ${ }^{5}$

Di tingkat pengadilan, kasus ini diupayakan agar diselesaikan dengan cara perdamaian antara korban dan tertuduh. Karena telah terjadi kesepakatan berupa perdamaian di antara mereka, korban dan tertuduh, pengadilan dalam putusannya melepaskan tertuduh dari segala tuntutan hukum. Dalam amar putusannya dinyatakan, antara lain, perbuatan tertuduh Ny. Ellya Dado terbukti dengan sah dan meyakinkan, baik tuduhan primair, subsidair, maupun subsidair lagi, tetapi perbuatan-perbuatan itu dengan penyelesaian secara damai di antara pihak-pihak, tidak merupakan suatu kejahatan ataupun pelanggaran yang dapat dihukum lagi, melepaskan tertuduh oleh karena itu dari segala tuntutan hukum. ${ }^{6}$ Putusan Pengadilan dalam kasus ini dijadikan yurisprudensi oleh Mahkamah Agung sehingga diikuti kaidah hukumnya dimana perdamaian dijadikan sebagai alasan pelepasan dari segala tuntutan hukum oleh Putusan Pengadilan selanjutnya.

Pada dasarnya dalam hal putusan lepas dari segala tuntutan hukum (onslag van recht vervolging) yang diatur dalam Pasal 191 ayat (2) KUHAP disebutkan bahwa apa yang didakwakan Penuntut Umum kepada terdakwa terbukti secara sah dan meyakinkan menurut hukum. Akan tetapi, terdakwa tidak dapat dipidana karena perbuatan yang dilakukan bukan merupakan tindak pidana. Pengertian bukan merupakan tindak pidana ini diartikan pada umumnya sebagai sebuah perbuatan dalam ruang lingkup hukum lain (selain pidana) yang mana peradilan pidana tidak berhak/ berwenang mengadilinya karena merupakan yuridiksi peradilan lain, seperti peradilan perdata, adat, dagang, dan sebagainya. ${ }^{7}$

Antonius Sudirman, Hati Nurani Hakim dan Putusannya: Suatu Pendekatan dari Perspektif Ilmu Hukum Perilaku (Bahavioral Jurisprudence) Kasus Hakim Bismar Siregar (Bandung: Citra Aditya Bakti, 2007), hlm. 200-201.

Ibid, hlm. 201.

Ibid.

Lilik Mulyadi, Hukum Acara Pidana Indonesia: Suatu Tinjauan Khusus Terhadap Surat Dakwaan, Eksepsi, dan Putusan Peradilan (Bandung: Citra Aditya Bhakti, 2012), hlm. 129-130. 
Barangkali hanya berupa quasi tindak pidana, tetapi seolah-olah penyidik dan penuntut umum melihatnya sebagai perbuatan pidana. ${ }^{8}$ Dalam konteks inilah ada "pelepasan dari penuntutan" terhadap tindakan pidana yang telah terbukti berdasarkan perdamaian para pihak tetapi dinyatakan "bukan" merupakan tindak pidana sehingga dihapuskan pemidanaannya.

Putusan progresif dalam kasus tersebut sesungguhnya merupakan upaya untuk mengembalikan filosofi pemidanaan berdasarkan hukum yang hidup dan sesuai dengan rasa keadilan masyarakat. Keadilan sosial bagi seluruh rakyat Indonesia dalam sistem kerakyatan yang dipimpin oleh hikmat kebijaksanaan yang berasaskan musyawarah setidaknya dapat tercermin dalam peradilan di Indonesia, tanpa harus diselesaikan melalui dimensi retributif dan berujung pada pidana penjara, sehingga nilai-nilai tersebut dapat terwujud nyata dalam sistem peradilan pidana yang "memanusiakan" dalam bentuk asas keseimbangan antara asas kemasyarakatan dan asas individualistik. Upaya hukum dalam peradilan Indonesia seperti proses rekonsiliasi (perdamaian) dapat menjadi salah satu acuan implikasi proses penegakan yang melibatkan korban, pelaku dan masyarakat, ${ }^{9}$ termasuk juga dalam konteks putusan pemidanaan dari hakim.

Praktik peradilan dengan pelepasan tuntutan hukuman ("tidak dianggap tindak pidana") berdasarkan perdamaian, seharusnya dapat diakomodasi oleh perumus kebijakan pembaruan hukum pidana nasional (RUU KUHP). Misi dekolonialisasi dalam sistem pemidanaan nasional penting dilakukan dengan mengakomodasi perkembangan nilai-nilai, standar-standar serta norma yang hidup dan berkembangan dalam kehidupan masyarakat hukum Indonesia. ${ }^{10}$ Menarik untuk diteliti beberapa persoalan yaitu tentang bagaimana kedudukan perdamaian dalam sistem pemidanaan yang dianut oleh hukum positif; bagaimana putusan pengadilan yang melepaskan tuntutan hukum berdasarkan perdamaian demi mewujudkan keadilan; dan bagaimana urgensi kedudukan perdamaian sebagai penghapus pemidanaan guna mewujudkan keadilan dalam pembaruan hukum pidana nasional.

\section{B. Metode Penelitian}

Penelitian ini menggunakan metode normatif. Terdapat 3 (tiga) pendekatan untuk mengkaji ketiga permasalahan yang coba dibahas dengan metode penelitian normatif ini yaitu pendekatan perundang-undangan (statute approach), pendekatan kasus (case approach) serta pendekatan konseptual (conseptual approach). Pendekatan perundangundangan diperlukan dalam rangka menelusuri ratio legis dan dasar ontologis lahirnya peraturan perundang-undangan. ${ }^{11}$ Pendekatan kasus digunakan untuk menemukan the ratio decidendi atau reasoning, yaitu pertimbangan pengadilan untuk sampai pada suatu putusan ${ }^{12}$

8 M. Yahya Harahap, Pembahasan Permasalahan dan Penerapan KUHAP: Pemeriksaan Sidang Pengadilan, Banding, Kasasi, dan Peninjauan Kembali (Jakarta: Sinar Grafika, 2009), hlm. 352.

$9 \quad$ Lilik Mulyadi, Implementasi Mediasi Penal Sebagai Perwujudan Nilai-Nilai Pancasila Guna Mendukung Supremasi Hukum Dalam Rangka Pembangunan Hukum Nasional (Yogyakarta: Genta Publishing, 2016), hlm. 6.

10 Badan Pembinaan Hukum Nasional. Naskah Akademik Rancangan Undang-Undang Tentang Kitab UndangUndang Hukum Pidana (KUHP). (Jakarta: Kementerian Hukum dan Hak Asasi Manusia, 2015), hlm. i.

11 Peter Mahmud Marzuki, Penelitian Hukum (Jakarta: Kencana, 2014), hlm. 93-94.

12 Ibid, hlm. 64. 
dimana letak terobosan hukum yang bertujuan memberi akses keadilan kepada para pihak. ${ }^{13}$ Pendekatan konseptual digunakan untuk memahami secara presisi dan akurat berbagai konsep yang digunakan oleh prinsip hukum dalam undang-undang maupun doktrin para ahli hukum. ${ }^{14}$

Sumber data yang digunakan dalam penelitian adalah data sekunder yang terdiri atas bahan hukum primer berupa peraturan perundang-undangan, konvensi hukum internasional dan putusan pengadilan serta bahan hukum sekunder berupa literatur dan hasil penelitian. Peraturan perundangundangan yang digunakan antara lain yang berkaitan dengan KUHP, Undang-Undang Nomor 11 Tahun 2012 tentang Sistem Peradilan Pidana Anak dan RUU KUHP serta konvensi internasional terkait restorative justice yaitu Declaration of Basic Principles of Justice for Victims of Crime and Abuse of Power (1985). Putusan pengadilan yang dikaji terkait dengan perkara dimana perdamaian dijadikan sebagai alasan menghapus tuntutan hukuman yaitu Putusan Pengadilan Negeri Jakarta Utara-Timur Nomor 46/Pid/78/UT/Wanita. Adapun literatur yang digunakan dalam kajian agar terhindar dari kekeliruan pandangan adalah yang berkaitan dengan filsafat pemidanaan dan teori restorative justice. Bahan-bahan hukum dan literatur tersebut dikumpulkan melalui metode sistematis dan dicatat dalam kartu antara lain permasalahannya, asas-asas, argumentasi, implementasi yang ditempuh, alternatif pemecahannya dan lain sebagainya. Data yang telah dikumpulkan kemudian dideskripsikan dan diinterpretasikan sesuai pokok permasalahan selanjutnya disistematisasi, dieksplanasi, dan diberikan argumentasi. Metode analisis yang diterapkan untuk mendapatkan kesimpulan atas permasalahan yang dibahas adalah melalui analisis yuridis kualitatif.

\section{Pembahasan}

\section{Kedudukan Perdamaian dalam Sistem Pemidanaan yang Dianut oleh Hukum Positif}

Lembaga perdamaian dalam sistem hukum nasional sesungguhnya telah lama ditetapkan khususnya pada bidang penyelesaian perkara perdata. Penerapan upaya perdamaian (lembaga dading) ditentukan dalam Pasal 130 HIR/Pasal 154 RBg. Pasca reformasi, Pemerintah memberlakukan Undang-Undang Nomor 30 Tahun 1999 tentang Arbitrase dan Alternatif Penyelesaian Sengketa. Undang-undang ini telah memberikan tempat khusus bagi keberadaan alternatif penyelesaian sengketa di luar proses litigasi.

Perdamaian merupakan cara penyelesaian sengketa yang terbaik, karena dengan adanya sengketa, diantara para pihak sesungguhnya sudah terjadi ketegangan atau setidak-tidaknya sudah terjadi ketidakharmonisan tersebut semakin lama akan menjadi semakin tajam yang menimbulkan permusuhan dan kebencian yang mendalam, sehingga hubungan baik, hubungan kekeluargaan akan hilang. Agar tercipta kembali hubungan harmonis diantara para pihak yang bersengketa, maka keinginan kedua pihak

\footnotetext{
13 Sulistyowati Irianto dan Lim Sing Meij, Praktik Penegakan Hukum: Arena Penelitian Sosiolegal Yang Kaya. Dalam Sulistyowati Irianto dan Shidarta. Metode Penelitian Hukum (Konstelasi dan Refleksi) (Jakarta: Yayasan Pustaka Obor Indonesia. 2011), hlm. 191.

14 Peter Machmud Marzuki, Op Cit, hlm. 178.
} 
yang saling bertentangan tersebut haruslah terpenuhi sehingga kedua pihak merasa puas kembali. Kepuasan yang dimaksudkan tersebut tidak saja terbatas pada substansi (materi) yang menjadi pokok persengketaan, juga menyangkut kepuasan psikologis. Hal tersebut dapat terwujud melalui penyelesaian sengketa secara damai. ${ }^{15}$

Secara bertahap Mahkamah Agung selaku lembaga peradilan tertinggi menerbitkan beberapa kebijakan pengaturan tentang mediasi yang selalu diperbaruinya yaitu melalui Surat Edaran Nomor 1 Tahun 2002 tentang Pemberdayaan Pengadilan Tingkat Pertama Menerapkan Lembaga Damai, Peraturan Mahkamah Agung Nomor 03 Tahun 2003 tentang Prosedur Mediasi di Pengadilan, Peraturan Mahkamah Agung Nomor 01 Tahun 2008 tentang Prosedur Mediasi di Pengadilan, dan Peraturan Mahkamah Agung Nomor 1 Tahun 2016 tentang Prosedur Mediasi di Pengadilan.

Bertahapnya perubahan ketentuan mediasi dalam rangka penyelesaian sengketa secara perdamaian diawali dengan ketentuan tentang pelaksanaannya di luar dan di dalam pengadilan dengan disertai prasyaratan yang juga mengalami perubahan yaitu dimana sebelumnya berupa himbauan kemudian menjadi kewajiban terhadap para pihak dan hakim. Refleksi akan perubahan tersebut menegaskan bahwa lembaga perdamaian dalam sistem hukum dan peradilan nasional sangat penting dan strategis keberadaannya dalam upaya penyelesaian sengketa di pengadilan. Peraturan-peraturan dari Mahkamah Agung ini diorientasikan sebagai instrumen untuk meningkatkan akses masyarakat terhadap keadilan sekaligus implementasi asas penyelenggaraan peradilan yang sederhana, cepat, dan berbiaya ringan. Mediasi merupakan cara penyelesaian sengketa secara damai yang tepat, efektif, dan dapat membuka akses yang lebih luas kepada Para Pihak untuk memperoleh penyelesaian yang memuaskan serta berkeadilan. ${ }^{16}$

Mediasi juga dikenal dalam perkara pidana, tetapi keberadaannya dalam penyelesaian perkara pidana dengan perdamaian yang melibatkan korban, pelaku dan masyarakat masih terbatas dan dilaksanakan di luar pengadilan. Dalam hal ini diistilahkan sebagai mediasi penal. Keberadaan dan pelaksanaan dari mediasi penal ini adalah di luar pengadilan. Mediasi penal tidak diatur dalam undang-undang melainkan hanya diatur secara parsial dan terbatas berupa Surat Kapolri Nomor Pol: B/3022/XII/2009/ SDEOPS tanggal 14 Desember 2009 tentang Penanganan Kasus Melalui Alternative Dispute Resolution (ADR) serta Peraturan Kepala Kepolisian Negara Republik Indonesia Nomor 7 Tahun 2008 tentang Pedoman Dasar Strategi dan Implementasi Pemolisian Masyarakat Dalam Penyelenggaraan Tugas Polri. Pada dasarnya, peraturan tersebut mengatur tentang penanganan kasus pidana melalui ADR dengan sifat kerugian materi kecil, disepakati para pihak, dilakukan melalui prinsip musyawarah mufakat, harus menghormati norma sosial/adat serta memenuhi asas keadilan dan apabila dicapai melalui ADR pelakunya tidak lagi disentuh oleh tindakan hukum lainnya. ${ }^{17}$

15 I Made Sukadana, Mediasi Peradilan: Mediasi dalam Sistem Peradilan Perdata Indonesia dalam Rangka Mewujudkan Proses Peradilan yang Sederhana, Cepat, dan Biaya Ringan, (Jakarta: Prestasi Pustaka, 2012), hlm. 159-160.

16 Konsideran Peraturan Mahkamah Agung Nomor 1 Tahun 2016 tentang Prosedur Mediasi Di Pengadilan.

17 Lilik Mulyadi, Implementasi Mediasi Penal....Op.Cit. hlm. 31-32. 
Selain secara terbatas eksistensi mediasi penal diatur oleh Peraturan Kapolri, dalam perspektif penyelesaian sengketa dan perkara pidana adat melalui perdamaian desa telah mendapat pengakuan di dalam sistem otonomi daerah yakni dalam Undang-Undang Nomor 22 Tahun 1999 tentang Pemerintahan Daerah dan Peraturan Pemerintah Nomor 76 Tahun 2001, Pasal 16 menyebutkan bahwa untuk mendamaikan perselisihan, Kepala Desa dapat dibantu Lembaga Adat Desa. Juga UndangUndang Nomor 21 Tahun 2001 tentang Otonomi Khusus Bagi Provinsi Papua mengamanatkan adanya dua sistem peradilan di Papua yaitu Peradilan Adat dan Pengadilan Negeri. Peradilan Adat menurut Pasal 51 ayat (1) adalah peradilan perdamaian lingkungan masyarakat hukum adat yang mempunyai kewenangan memeriksa dan mengadili sengketa perdata adat dan perkara pidana di antara para warga masyarakat hukum adat yang bersangkutan. ${ }^{18}$ Penerapan dari peradilan perdamaian dalam perkara pidana di lingkungan masyarakat adat ini tidak dapat diberlakukan untuk pelaku pidana yang bukan masyarakat hukum adatnya. ${ }^{19}$

Pada perkembangan selanjutnya, perdamaian dalam perkara pidana yang berkaitan dengan anak mendapatkan dasar pelaksanaannya dalam Undang-Undang Nomor 11 Tahun 2012 tentang Sistem Peradilan Pidana Anak. Penegak hukum dan hakim diwajibkan menyelenggarakan diversi. Secara asas, lembaga diversi merupakan representasi dari pendekatan restorative justice dalam sistem peradilan pidana anak. Pendekatan restorative justice memiliki kekuatan yang mampu memulihkan hubungan antar pihak yang menjadi pelaku dan yang menjadi Korban. Juga mencegah adanya permusuhan lebih mendalam antar pihak dan mendorong rekonsiliasi antara pihak pelaku dan Korban secara sukarela. Kekuatan lain ialah mendorong adanya partisipasi warga masyarakat lainnya misalnya anggota keluarga atau tetangga serta menekankan pentingnya peran Korban dalam suatu proses menuju keadilan. ${ }^{20}$ Penerapan diversi dapat dilakukan di dalam semua tingkatan pemeriksaan, dimaksudkan untuk mengurangi dampak negatif keterlibatan anak dalam proses peradilan tersebut. ${ }^{21}$ Melalui peraturan yang cukup revolusioner ini, diharapkan Indonesia dapat memberikan perlindungan dan keadilan yang utuh bagi anak. ${ }^{22}$

Penyelesaian perkara Pidana melalui mekanisme non formal, seringkali dinilai lebih memuaskan karena lebih menguntungkan kedua belah pihak. Mediasi Penal sebagai salah satu mekanisme diluar peradilan, acapkali dipraktikkan dan mendapat respon baik daripada penyelesaian melalui jalur peradilan. Hal ini tidak lepas dari prinsip penyelesaian perkara yang mendasar kepada prinsip musyawarah dalam Hukum Adat dan Hukum Islam. Perselisihan dalam Hukum Adat dapat diselesaikan melalui Mediasi, yang dipimpin oleh para tetua adat. Sedangkan dalam Hukum Islam, Mediasi

18 M. Hatta Ali, Peradilan Sederhana, Cepat \& Biaya Ringan Menuju Keadilan Restoratif (Bandung: Alumni, 2012), hlm. 352 .

19 Ibid, hlm. 353.

20 Sunarso, Siswanto, Viktimologi Dalam Sistem Peradilan Pidana, (Jakarta: Sinar Grafika, 2012), hlm. 157.

21 Sri Rahayu, "Diversi Sebagai Alternatif Penyelesaian Perkara Tindak Pidana Yang Dilakukan Anak Dalam Perspektif Sistem Peradilan Pidana Anak", Jurnal Ilmu Hukum (2015), hlm. 133.

22 Yutirsa Yunus, "Analisis Konsep Restoratif Justice Melalui Sistem Diversi Dalam Sistem Peradilan Pidana Anak Di Indonesia" Jurnal Rechtsvinding Volume 2 Nomor 2 Agustus (2013), hlm. 244. 
terjadi dalam bentuk Jarimah Qisas Diyat, yang sebenarnya terbatas kepada perkara tertentu saja. Mediasi yang tidak dikenal dalam Hukum Pidana Modern, sudah sepatutnya dijadikan alternatif penyelesaian perkara pidana. ${ }^{23}$ Olehnya perlu dilakukan rekonstruksi hukum pidana nasional sebagai hukum publik (algemen belangen) dimana negara tidak memerankan sepenuhnya pembalasan hukuman atas suatu tindak pidana yang korbannya adalah individu.

Bilamana individu sebagai korban tersebut telah terkembalikan kerugiannya dan telah memaafkan pelaku melalui perdamaian, baik yang dilakukan diluar maupun didalam atau saat persidangan di pengadilan maka seharusnya tidak berdasar lagi Negara melalui Penuntut Umum atau hakim untuk (memaksakan diri) tetap menjatuhkan pemidanaan. Filsafat pemidanaan yang memutlakkan retributive justice harus diperbarui dengan pemidanaan restoratif. Pemidanaan restoratif dalam sistem peradilan adalah yang memandang bahwa posisi korban yang menderita luka atau kehilangan nyawa akibat kekerasan terhadap kemanusiaan tidak akan mungkin bisa diganti oleh keadilan hukum dan hanya mungkin bila kompensasinya diserahkan kepada korban untuk merumuskan dan di pihak lain ada aksi riil bagi keluarga korban dalam soal pendidikan atau santunan kemanusiaan yang melambangkan secara ikhlas sikap tobat dan minta maaf dalam tindakan restorasi kemanusiaan yang dirumuskan korban. Pemidanaan restoratif menekankan pada restitusi oleh pelaku kepada korban daripada restribusi kepada Negara. ${ }^{24}$ Dalam konteks ini perdamaian menjadi instrumen efektif dan efisien untuk memulihkan kondisi akibat terjadinya tindak pidana secara harmonis antara korban dan pelaku serta keluarganya. Sayangnya hukum positif tidak memungkinkan menghapuskan pemidanaan berdasarkan perdamaian kecuali dalam hal perkara pidana anak dimana diversi diakui eksistensinya.

\section{Putusan Pengadilan yang Mengha- puskan Pemidanaan Berdasarkan Perdamaian Demi Mewujudkan Keadilan}

Praktik peradilan pidana umumnya menjadikan perdamaian yang dilakukan antara korban dengan pelaku tindak pidana menjadi bahan pertimbangan meringankan yang digunakan oleh sebagian besar hakim dalam menjatuhkan putusannya. Perdamaian yang dilakukan antara korban dengan pelaku tindak pidana tidak dapat menghapuskan pertanggungjawaban atau perbuatan yang telah dilakukan oleh terdakwa meskipun sudah ada surat pernyataan yang dibuat oleh pelaku dan korban yang pada intinya korban sudah memaafkan terdakwa dan tidak akan menuntut terdakwa atas perbuatannya, bahkan meminta petugas untuk membebaskan terdakwa dari pemidanaan. Alasan dalam praktik pengadilan bahwa perdamaian antara korban dengan pelaku tindak pidana tidak dapat menghapuskan pemidanaan menurut Alef Musyahadah antara lain: ${ }^{25}$

\footnotetext{
Faizal Adi Surya. "Tinjauan Mediasi Penal Dalam Perspektif Hukum Adat dan Hukum Islam". Jurnal Jurisprudence, Volume 5 Nomor 2 September (2015), hlm. 44.

24 M. Hatta Ali. Op Cit. hlm. 314.

25 Alef Musyahadah R, "Kedudukan Perdamaian Antara Korban Dengan Pelaku Tindak Pidana Dalam Sistem Pemidanaan" Tesis. (Semarang: Program Pasca Sarjana Universitas Diponegoro, 2005), hlm. 142-143.
} 
1) Perkara yang dilakukan bukan merupakan delik aduan sehingga tetap tidak dapat menghapus pertanggungjawaban pidana;

2) Perdamaian yang dilakukan antara korban dengan pelaku fungsinya sebagai pendekatan humanity dalam menjatuhkan pidana, seperti usia yang muda, wanita hamil, tulang punggung keluarga; dan

3) Dalam perkara pidana, perdamaian masih terbuka pada tingkat penyidikan sedangkan jika perkara sudah sampai ke tingkat pengadilan/mulai diperiksa di persidangan, maka hakim akan memeriksa berdasarkan surat dakwaan yang diajukan oleh jaksa penuntut umum.

Para hakim yang visioner atau berwawasan luas dan jauh ke depan akan selalu mempertimbangkan agar perkara pidana yang sedang diperiksa dan diputuskan dapat memenuhi rasa keadilan baik bagi pelaku tindak pidana maupun bagi pihak korban. Tidak semua hakim yang menangani perkara pidana memiliki kepekaan dalam menangkap tanda-tanda yang menyertai perkara yang ditanganinya sehingga perlu diberikan perhatian ekstra kepada kondisi psikis pihak korban dan pelaku tindak pidana. Hanya hakim yang berwawasan progresif dapat melakukan kegiatan ekstra semacam "upacara" perdamaian antara pelaku tindak pidana dengan korban yang telah disakiti atau dirugikannya, baik dengan sengaja ataupun karena kelalaiannya. Dengan memerintahkan terdakwa untuk meminta maaf kepada korban, dan menyatakan penyesalan atas perbuatan yang telah menyakiti korban, dengan dilakukan secara tulus dan ikhlas akan memberikan pengaruh posistif berupa pemulihan trauma psikis yang dialami korban, ${ }^{26}$ selainnya juga menjadi insentif bagi pelaku dengan keringanan pemidanaan.

Peringanan hukuman dalam putusan pengadilan atas terjadinya perdamaian yang berdampak pada pemaafan korban sudah lazim keberadaannya. Di luar kelaziman tersebut, terdapat putusan Pengadilan Negeri Jakarta Utara-Timur Nomor 46/Pid/78/UT/Wanita yang memberikan pelepasan dari tuntutan hukuman atas terjadinya perdamaian. Di tingkat pengadilan, kasus ini diupayakan agar diselesaikan dengan cara perdamaian antara korban dan tertuduh. Karena telah terjadi kesepakatan berupa perdamaian di antara mereka, korban dan tertuduh, pengadilan dalam putusannya melepaskan tertuduh dari segala tuntutan hukum. Dalam amar putusannya dinyatakan, antara lain, perbuatan tertuduh Ny. Ellya Dado terbukti dengan sah dan meyakinkan, baik tuduhan primair, subsidair, maupun subsidair lagi, tetapi perbuatan-perbuatan itu dengan penyelesaian secara damai di antara pihak-pihak, tidak merupakan suatu kejahatan ataupun pelanggaran yang dapat dihukum lagi, sehingga hakim pun melepaskan tertuduh oleh karena itu dari segala tuntutan hukum. Adapun dalam konsideran putusannya dikemukakan beberapa hal sebagai berikut:27

Menimbang bahwa karenanya pengadilan mempertimbangkan berdasarkan persetujuan antara pihak-pihak tentang penyelesaian secara damai walaupun perbuatan tertuduh berdasarkan pengakuannya juga supaya bukti

\footnotetext{
26 Natangsa Surbakti, Peradilan Restoratif: Dalam Bingkai Empiris, Teori dan Kebijakan. (Yogyakarta: Genta Publishing, 2015), hlm. 204-205.

27 Antonius Sudirman. Op Cit. hlm. 202.
} 
lainnya telah terbukti melakukan perbuatan yang dituduhkan, baik tuduhan primair, subsidair, maupun subsidair lagi sehingga dari tuduhan yang terbukti itu, tuduhan primair-lah yang patut dipersalahkan atas diri tertuduh, kepada saksi Devy disarankan menyampaikan penyampaian pernyataan maaf kepada tertuduh dan telah diterima oleh tertuduh sehingga secara fakta telah dapat diselesaikan persoalan antara saksi dan tertuduh.

Menimbang bahwa pernyataan tersebut patut dipertimbangkan, sepanjang belum pernah ataupun belum ada yurisrudensi perkara itu, tetapi tidak tertutup ataupun dilarang dipertimbangkan penyelesaian seperti demikian, pengadilan pada kesempatan ini akan mempertimbangkan sebagai berikut:

a) Bahwa hakikat peradilan dan memberi keadilan ialah memulihkan kembali "kegalingan" (kepincangan) hubungan antara anggota masyarakat yang terganggu, baik secara umum maupun secara khusus karena perbuatan seseorang;

b) Bahwa dalam hal ini sebagai nyata dalam pernyataan dan penerimaan maaf, demikian pula kesepakatan ganti rugi atau kesanggupan mengganti rugi antara pihakpihak akibat perbuatan telah dipulihkan, karenanya tidak melihat sesuatu alasan yang sangat prinsipil untuk menerapkan hukum secara harfiah atas perbuatan yang terbukti itu, bahkan adanya hukuman demikian akan menimbulkan, setidaktidaknya akan meninggalkan cacat batin yang sesungguhnya tidak perlu lagi ada di antara pihak-pihak;

c) Bahwa dalam penyelesaian perkara secara kekeluargaan, baik sebelum atau selama di persidangan, pengadilan patut dipertimbangkan yang demikian itu berdasarkan penjelasan Pasal 14 ayat (1) Undang-Undang Nomor 14 tahun 1970, yakni sebagai hakim yang bijaksana, berdasarkan pertimbangan hubungan baik antara pihakpihak, menyatakan perbuatan yang terbukti itu tidak lagi merupakan perbuatan yang dapat dituntut hukuman.

Menariknya putusan dengan pertimbangan hukum di atas, bahwa perdamaian diantara pelaku dan korban dijadikan dasar untuk melepaskan terdakwa dari segala tuntutan hukum. Majelis hakim tidak melihat alasan prinsipil bahwa perbuatan tersebut layak diterapkan pemidanaan sehingga harus dinyatakan lepas dari segala tuntutan hukum. Pada dasarnya putusan pelepasan dari segala tuntutan hukum menurut Alfitra dapat diartikan dalam dua arti, yaitu dalam arti sempit dan dalam arti luas.: ${ }^{28}$

1. Pelepasan dari segala tuntutan hukum dalam arti luas, di sini termasuk pembebasan yang sebenarnya merupakan pelepasan dari segala tuntutan hukum, tetapi karena telah disebut sebagai pembebasan, maka disebut pelepasan dari segala tuntutan hukum yang bersifat tertutup. Pembebasan yang hakikatnya pelepasan dari segala tuntutan hukum (ontslag van alle vervolging), dipakai: Pertama, bila perbuatan yang didakwakan tidak merupakan tindak pidana, di dalamnya termasuk jika perbuatan yang didakwakan tidak mengandung segala unsur yang dikehendaki oleh undang-undang (Misalnya, Pasal 338 KUHP tidak disebut unsur sengaja dalam surat dakwaan). Atau bila perbuatan

28 Alfitra, Hapusnya Hak Menuntut Menjalankan Pidana (Depok: Raih Asa Sukses, 2012), hlm. 13-14. 
itu kehilangan sifat melawan hukumnya perbuatan. Misalnya, bila perbuatan itu dilakukan untuk membela diri menurut syarat undang-undang Pasal 49 KUHP. Kedua, bila terdakwa, perbuatan yang didakwakan merupakan tindak pidana, tetapi tidak dapat dipersalahkan kepadanya, termasuk hal-hal yang merupakan kekuasaan relatif tidak dapat diatasi dan keadaan jasmaniah yang tidak memungkinkan bertanggungjawab atas perbuatannya (ontrekeningssvatbaarheid).

2. Pelepasan dari tuntutan hukum dalam arti sempit (verkapte ontslag van rechtsvervolging). Dalam hal ini jika hakim berpendapat unsur-unsur tindak pidana tidak terbukti, tetapi pendapatnya keliru karena salah satu unsur diartikan salah, tidak sesuai dengan maksud undang-undang. Di sini hakim menggunakan kriteria subjektif sebagai manusia pribadi yang tidak sesuai dengan kriteria objektif yang harus diturut. Misalnya, memberikan arti aliran listrik dalam surat dakwaan karena kata barang dalam unsur Pasal 362 KUHP, secara objektif mengandung pengertian listrik.

Putusan lepas dari segala tuntutan hukum dimaknai dalam putusan di atas bahwa perbuatan terdakwa telah terbukti dan memenuhi unsur pasal yang didakwakan Jaksa Penuntut Umum, tetapi tidak dapat diputus pemidanaannya karena dipandang bukan merupakan tindak pidana. Secara doktrin, makna bukan merupakan tindak pidana adalah memang sesungguhnya bukan rezim hukum pidana, misalnya hukum perdata atau hukum dagang dan lain-lain yang kompetensinya bukan wilayah peradilan pidana. Sebagaimana wanprestasi yang dipaksakan masuk dan diproses oleh penegak hukum, tetapi begitu sampai di hadapan persidangan, hakim dalam putusannya menganggap perbuatan tersebut bukanlah penipuan tetapi wanprestasi. Sementara itu dalam perkara Ny. Ellya Dado ini, yang dimaknai pelepasan dari segala tuntutan hukum ini oleh majelis hakim bukan masalah kualifikasi tindak pidananya yang dianggap bukan merupakan tindak pidana. Akan tetapi sifat melawan hukumnya yang dihilangkan oleh majelis hakim dengan pertimbangan bahwa dengan adanya perdamaian maka kepincangan sosial akibat tindak pidana sudah terpulihkan dan bilamana masih harus dikenakan pemidanaan maka kondisi yang sudah pulih dan harmonis akan kembali terguncang.

Van Bemmellen menyatakan bahwa masih ada dua hal yang harus diputuskan untuk dilepaskan dari tuntutan hukum. Hal-hal ini terjadi apabila bagian-bagian dari suatu perbuatan sebagaimana yang didakwakan, juga dinyatakan dan dapat dibuktikan serta memenuhi semua bagian dari perumusan delik. Akan tetapi, baik perbuatan ataupun pelakunya karena suatu alasan, tidak dapat dipidana. Dilarangnya suatu perbuatan dan diancamnya pidana dari pelakunya, tidak hanya turut diperhitungkannya bagian-bagian dari suatu perbuatan, sebagaimana dirumuskan dalam lukisan delik, tetapi juga berlaku syaratsyarat yang timbul dalam asas-asas hukum umum yang sudah diterima (melawan hukum materiil). ${ }^{29}$ Dalam konteks menerima tidak adanya melawan hukum materiil dalam suatu

29 Eva Achjani Zulva, Gugurnya Hak Menuntut: Dasar Penghapus, Peringan, dan Pemberat Pidana (Bogor: Ghalia Indonesia, 2010), hlm. 115. 
perbuatan yang melanggar undang-undang ini, Van Veen menjelaskan bahwa hakim sebetulnya mengambil tempat yang diduduki oleh pembuat undang-undang. ${ }^{30}$

Merupakan hal yang lazim jika hakim menyatakan suatu perbuatan yang tidak jelas ketentuannya dalam undang-undang melalui upaya penemuan hukumnya guna memberikan keadilan dalam suatu masyarakat dimana dalam hukum kebiasaannya menyatakan hal itu adalah perlu dipidana. Tetapi fungsi lainnya ternyata hakim pun bisa menegasikan suatu perbuatan yang sudah jelas merupakan tindak pidana sebagaimana diatur dalam undangundang, tetapi karena dipandang perbuatan tersebut sudah tidak layak lagi untuk dijatuhkan pemidanaan maka hakim dapat menghapus sifat melawan hukumnya perbuatan tersebut sehingga terhapuslah pemidanaannya. Dalam konteks ini Utrecht menyatakan bahwa dasar penghapus pidana yang umum ini didasarkan ketiadaan sifat melawan hukum dari perbuatan atau ketiadaaan kesalahan dalam pengertian yang luas. Sementara dasar penghapusan pidana yang khusus adalah pada kepentingan umum yang tidak diuntungkan dengan adanya penuntutan pidana. ${ }^{31}$

Disamping apa yang ditentukan dalam undang-undang, praktik pengadilan juga menerima beberapa macam keadaan atau kondisi yang dapat menghapuskan pemidanaan yang berkembang dan diterima sebagai suatu doktrin. ${ }^{32}$ Sifat melawan hukum materiil dalam fungsinya yang negatif merupakan alasan pembenar. Argumentasinya, hakikat dari perbuatan pidana adalah perbuatan antisosial, sehingga jika terdapat keragu-raguan dalam pengertian di satu-sisi telah memenuhi unsur delik, namun di sisi lain tidak bertentangan dengan rasa keadilan masyarakat. ${ }^{33}$ Putusan Pengadilan Negeri Jakarta Utara-Timur Nomor 46/Pid/78/ UT/Wanita menerobos dan memberikan kaidah hukum baru bahwa perdamaian diantara korban dan pelaku dapat dijadikan dasar alasan penghapusan pemidanaan. Selanjutnya oleh Mahkamah Agung dan putusan pengadilan di kemudian hari, putusan ini diikuti dan dijadikan yurisprudensi.

\section{Kedudukan Perdamaian Sebagai Penghapus Pemidanaan Guna Mewujudkan Keadilan Dalam Pembaruan Hukum Pidana Nasional}

Realitas putusan pengadilan berikutnya yang menahbiskan putusan Pengadilan Negeri Jakarta Utara-Timur Nomor 46/Pid/78/UT/ Wanitasebagai yurisprudensi merupakan sebuah refleksi kegelisahan para hakim yang berhadapan secara langsung dengan eksistensi hukum pidana yang kurang selaras dengan nilai keadilan masyarakat dimana perdamaian tidak dapat dijadikan alasan penghapus pemidanaan. Bukan tanpa alasan, sebuah putusan dikategorisasi sebagai yurisprudensi melainkan didalamnya mengangkat kaidah hukum baru yang menerobos perundang-undangan yang ada sebagai usaha membentuk hukum atau menguji hukum berdasarkan nilai-nilai moralitas

Ibid, hlm. 117.

Ibid, hlm. 47.

Ibid.

Eddy O.S. Hiariej, Prinsip-Prinsip Hukum Pidana (Yogyakarta: Cahaya Atmaka Pustaka, 2014), hlm. 238. 
tertinggi, seperti keadilan dan kebenaran. ${ }^{34}$ Hakim pun didorong untuk melakukan pembentukan hukum baru yang berfungsi sebagai a tool of social engineering. Tidak sedikit yurisprudensi yang telah menimbulkan berbagai perubahan besar dalam praktek penegakan dan pengembangan hukum sehingga menginspirasi pembaruan hukum dalam politik legislasi (DPR). ${ }^{35}$ Dalam konteks yang demikian, muncul pemikiran yang berpendapat bahwa adil tidaknya suatu undang-undang berada di pundak Hakim. ${ }^{36}$

Pada dasarnya penciptaan yurisprudensi dapat ditelusuri dari uraian pertimbangan hukum (ratio decidendi) dalam putusan hakim. Dalam rumusan pertimbangan hukum itu dapat ditelusuri kandungan asas-asas hukum bersifat umum, ketentuan asas-asas hukum dalam peraturan konkret atau kandungan penerapan hukum sesuai sistem hukum. Adanya ketiga unsur dalam pertimbangan hakim telah cukup dijadikan patokan untuk menentukan status putusan hakim tersebut sebagai yurisprudensi. Dengan menemukan kandungan unsur-unsur dalam setiap putusan hakim, dapat juga dikatakan bahwa pada setiap yurisprudensi itu menurut H.P. Panggabean dapat ditemukan adanya nilai (value) dalam 3 klasifikasi, yaitu: ${ }^{37}$

1. Klasifikasi konstitutif, jika dalam rumusan yurisprudensi tersebut lebih ditonjolkan aspek hukum konstitusional dalam orientasi penegakan rechts idée dan nilai-nilai hukum global yang terkandung dalam UUD 1945 dan
Pancasila. Yurisprudensi dalam klasifikasi mencakup sengketa yang berkaitan dengan penegakan hukum yang mengandung sifat nasional atau global. Seperti hukum HAM, hukum lingkungan hidup dan hukum yang berorientasi pada penegakan demokratisasi, dll;

2. Klasifikasi konstruktif, jika dalam rumusan yurisprudensi itu telah ditemukan penerapan ketiga unsur konstruksi nilai kaidah hukum yang terdiri atas unsur kepastian hukum, kemanfaatan, dan adil/patut secara proporsional; dan

3. Klasifikasi sosiatif atau efektif, dapat disarikan dari pandangan yang menyatakan bahwa untuk mewujudkan yurisprudensi yang bernilai "the maturity of law" diperlukan parameter rasional, praktis, dan aktual. Dengan parameter itu dapat ditemukan yurisprudensi ("hukum") yang matang untuk dipublikasikan mengatur ketertiban dalam menegakkan kepastian hukum dalam lalu lintas pergaulan masyarakat.

Konteks rumusan yurisprudensi bahwa perdamaian dapat menghapuskan pemidanaan tersebut sangat menonjolkan aspek hukum konstitusional dalam orientasi penegakan rechts idée dan nilai-nilai hukum global yang terkandung dalam UUD 1945 dan Pancasila. Penyelesaian perkara pidana dimana dalam persidangan telah dinyatakan pemberian maaf dan adanya ganti kerugian korban secara prinsipil tidak lagi

34 Deni Setyo Bagus Yuherawan, Dekonstruksi asas Legalitas Hukum Pidana: Sejarah Asas Legalitas dan Gagasan Peembaharuan Filosofi Hukum Pidana (Malang: Setara Press, 2014), hlm. 231-232.

35 Budi Suhariyanto, "Eksistensi Pembentukan Hukum Oleh Hakim Dalam Dinamika Politik Legislasi Di Indonesia" Jurnal Rechtsvinding Volume 4 Nomor 3 Desember (2015), hlm. 429.

36 Ahmad Kamil, Filsafat Kebebasan Hakim (Jakarta: Kencana Prenada Media, 2012), hlm. 211.

37 H.P. Panggabean, Penerapan Teori hokum Dalam Sistem Peradilan Indonesia. (Bandung: Alumni, 2014), hlm. 262263. 
diperlukan penerapan pemidanaan terhadapnya karena jika diterapkan maka akan meninggalkan cacat batin yang sesungguhnya tidak perlu lagi ada. Dalam perspektif ini, yurisprudensi memandang bahwa tujuan pemidanaan tidak semata-mata untuk pemberian penjeraan melalui pembalasan, tetapi harus juga ditujukan untuk memulihkan kembali terganggunya keharmonisan masyarakat. Tujuan pembalasan dengan menerapkan pemidanaan terhadap perdamaian diantara korban dan pelaku harus diganti atau disimpangi karena keadilan itu adalah pemulihan harmoni. Jika harmonisasi telah terbangun kembali maka tidak ada hak lagi untuk dijatuhkan pemidanaan oleh Negara terhadap para pihak yang sesungguhnya telah berdamai.

Sejatinya yurisprudensi ini menampakkan tentang urgensi pergeseran pemahaman tentang kejahatan dan tujuan pemidanaan terhadap pelakunya menuju pada keadilan restoratif. Konsep bahwa kejahatan itu merupakan pelanggaran terhadap orang dan hubungan antar orang dan pelanggaran melahirkan kewajiban dan tanggung jawab, prinsip-prinsip yang terkandung dalam keadilan restoratif menurut M. Hatta Ali adalah: ${ }^{38}$

1. Kejahatan adalah suatu pelanggaran terhadap hubungan kemanusiaan;

2. Korban dan masyarakat adalah pusat dari proses keadilan;

3. Prioritas pertama dalam proses keadilan adalah membantu korban;

4. Prioritas kedua adalah memulihkan masyarakat semaksimal mungkin;
5. Pelaku yang melanggar mempunyai tanggung jawab pribadi kepada korban dan kepada masyarakat untuk kejahatan yang telah dilakukan;

6. Merupakan tanggung jawab semua yang berkepentingan (stakeholder) untuk keadilan restoratif melalui kemitraan melakukan tindakan (partnerships for action); dan

7. Pelaku akan memperbaiki kompetensi dan pemahamannya sebagai akibat dari pengamannya dalam keadilan restoratif.

Adalah sebuah keniscayaan Hakim harus aktif mengikuti perkembangan perasaan keadilan yang sedang hidup dan berkembang pada masyarakat. Perkembangan kekinian telah memperlihatkan bahwa terdapat pergeseran paradigma keadilan, yaitu dari keadilan retributif menuju keadilan restoratif. Restorative justice secara perlahan dijadikan paradigma baru yang menutupi kekurangan daripada paradigma retributive justice. $^{39}$ Secara tepat konsep filsafat pemidanaan dalam Rancangan KUHP (Tahun 2015) mengakomodasi pemidanaan sebagai sarana menyelesaiakan konflik yang ditimbulkan oleh tindak pidana, memulihkan keseimbangan dan mendatangkan rasa damai dalam masyarakat (Pasal 55 ayat 1 huruf c). Demikian futuristiknya tafsir dari yurisprudensi tentang perlunya pelepasan pemidanaan terhadap pelaku yang telah berdamai dengan korban dan korban pun mendapatkan ganti kerugiannya sehingga harmonisasi sosial telah pulih kembali. Refleksi keadilan yang ditangkap oleh jurisprudensi tidak terlepas

$38 \quad$ M. Hatta Ali. Op Cit. hlm. 326.

39 Budi Suhariyanto, "Perlindungan Hukum terhadap Korban Kejahatan Dalam Sistem Peradilan Pidana Ditinjau Dari Perspektif Restoratif Justice" (Jakarta: Pusat Penelitian dan Pengembangan Mahkamah Agung, 2013), hlm. 134. 
dari hasil penangkapan realitas nilai hukum yang hidup dalam masyarakat yang notabene tidak diakomodasi oleh perundang-undangan (hukum pidana).

Sistem peradilan pidana dewasa ini masih menganut konsep bahwa perkara pidana adalah merupakan "sengketa" antara individu dengan masyarakat (publik) dan sengketa itu akan diselesaikan oleh Negara (pemerintah) sebagai wakil dari publik. Sekalipun HIR telah digantikan KUHAP tetapi konsep itu tetap belum berubah. Sengketa itu sendiri adalah berhubungan dengan salah satu atau beberapa substansi dari pasal yang sudah diatur dan diancam dengan hukuman dalam hukum pidana materiil yang saat ini ditentukan dalam KUHP dan di luar KUHP. Individu terlibat dalam sengketa itu yakni sebagai subjek hukum disebut "tersangka" atau "terdakwa". Dalam penyelesaian "sengketa" ini dianut suatu konsep bahwa Negara akan selalu berbuat baik bagi warga negaranya termasuk para pencari keadilan dalam perkara pidana. Konsep ini agaknya pengaruh dari zaman theokrasi dalam abad pertengahan (holly inquition), yang dalam perkembangannya sudah ditinggalkan. Namun konsep itu tanpa disadari masih dipertahankan dalam sistem peradilan pidana yang ada dewasa ini. ${ }^{40}$ Dalam konteks ini Iwa Kusuma Sumantri menyerukan untuk merevolusionisasikan hukum di Indonesia supaya masyarakat Indonesia dikuasai oleh hukum yang nasional dan layak bagi masyarakat. ${ }^{41}$

Secara asas, permusyawaratan (nilai sila keempat Pancasila) yang digunakan sebagai sarana perdamaian sehingga menghasilkan pemaafan diantara pelaku dan korban maupun keluarga serta masyarakat yang berkepentingan merupakan elemen utama dari pola penyelesaian perkara yang secara historis-sosiologis telah ada di dalam berbagai masyarakat di Indonesia ${ }^{42}$ sejak zaman prakolonialisme, kemudian tergerus pada zaman kolonialisme yang menghendaki penerapan positivisme dan kodifikasi hukum $^{43}$ yang bersifat individualisme. Olehnya perlu ada pembaruan hukum pidana nasional yang berorientasi pada upaya dekolonialisasi KUHP peninggalan/warisan kolonial, demokratisasi hukum pidana, konsolidasi hukum pidana,

40 Luhut M.P. Pangaribuan, Hukum Acara Pidana: Surat Resmi Advokat di Pengadilan. (Jakarta: Papas Sinar Sinanti, 2014), hlm. 18-19.

41 KUHP saat ini adalah warisan dari Pemerintah Kolonial Hindia Belanda (tahun 1915). Berlakunya berdasarkan ex Pasal 142 UUDS jo. Pasal 192 Konstitusi RIS jo. Proklamasi Presiden Soekarno tertanggal 10 Oktober 1945 Nr 2. Hingga sekarang masih tetap berlaku dan belum diganti oleh suatu kitab hukum pidana nasional Indonesia. Sejak mulai berlakunya, KUHP ini bukan suatu kitab hukum pidana yang modern dan telah terbelakang pada jamannya. KUHP ini adalah suatu copy dari Nederlands Strafwetboek dari tahun 1881 yang notabene lebih tua 34 tahun. Walaupun KUHP ini mengalami beberapa perubahan tetapi masih juga tetap orang dapat membuat komentar bahwa KUHP sangat-sangat terbelakang pada ilmu hukum pidana dan kriminologi dari jaman sekarang. E. Utrecht. Hukum Pidana I: Rangkaian Sari Kuliah. (Jakarta: Penerbitan Universitas, Tanpa Tahun), hlm. 52-56.

42 Natangsa Surbakti. Op Cit. hlm. 295.

43 Von Savigny menjelaskan bahwa kodifikasi hukum selalu membawa serta suatu efek yang negatif, yakni menghambat perkembangan hukum. sejarah berjalan terus, tetapi hukum sudah ditetapkan, maka menghentikan sejarah pada suatu waktu tertentu. Lagipula untuk merumuskan hukum yang sesuai dengan jiwa bangsa, perlu diselidiki dulu apa sebenarnya semangat jiwa bangsa, manakah keyakinan-keyakinan bangsa yang dapat dijadikan dasar sesuatu tata hukum yang memadai. Kalau hal ini dilalaikan maka akan timbul bahaya adanya jurang antara jiwa bangsa dan hukum yang terkandung dalam tata hukum negara. Theo Huijbers. Filsafat Hukum dalam Lintasan Sejarah. (Yogyakarta: Kanisius. 1982), hlm.119. 
dan adaptasi dan harmonisasi terhadap berbagai perkembangan hukum yang terjadi baik sebagai akibat perkembangan di bidang ilmu pengetahuan hukum pidana maupun perkembangan nilai-nilai, standar-standar serta norma yang hidup dan berkembangan dalam kehidupan masyarakat hukum Indonesia dan dunia internasional, sekaligus sebagai refleksi kedaulatan nasional yang bertanggungjawab. ${ }^{44}$

Nilai kerakyatan dan permusyawaratan perwakilan dalam Pancasila harus dimanivestasikan dalam pembentukan norma hukum pidana menggunakan prosedur yang demokratis, terbuka, adil, dan partisipatif. Seperti faham "legalitas" juga mempertimbangkan "living law". Seperti dalam RUU KUHP Pasal 1 ayat (3) menegaskan keberpihakan pada "living law" nilai-nilai hukum yang hidup dalam masyarakat. Ketentuan ini tidak mengurangi berlakunya hukum yang hidup dalam masyarakat yang menentukan bahwa seseorang patut dipidana walaupun perbuatan tersebut tidak diatur dalam peraturan perudang-undangan, sepanjang sesuai dengan nilai-nilai Pancasila dan/atau prinsip-prinsip hukum umum yang diakui oleh masyarakat bangsa-bangsa. Diberikannya ruang/peluang untuk menyelesaikan lewat mekanisme mediasi dalam perkara pidana (mediasi penal). ${ }^{45}$
Perdamaian yang didasari adanya kebutuhan pemaafan perlu dielaborasi dalam proses penanganan perkara pidana, baik sebelum atau di luar pengadilan maupun saat atau dalam proses persidangan di pengadilan. Hal ini dilakukan untuk memulihkan bargaining position $^{46}$ hak-hak asasi manusia korban yang selama ini dipinggirkan. Sebagaimana praktik pemberian diyat dalam hukum Islam yang pada hakikatnya merupakan bentuk perlindungan kepada korban kejahatan di satu pihak, di lain pihak merupakan bentuk pidana pengganti karena dilaksanakannya ajaran pemaafan yang sangat dianjurkan dalam Al Qur'an dan Sunah Nabi. Pemberian diyat juga melindungi serta meringankan beban tersangka. Selain itu, dengan pemberian diyat mengembangkan prinsip kedamaian hidup antar manusia dan dengan semangat silaturahim dan saling memaafkan terhadap segala kemungkinan kesalahan dalam pergaulan bersama dalam masyarakat. ${ }^{47}$

Penyelesaian perkara yang tidak memenuhi rasa keadilan bagi para korban tindak pidana, telah diakui oleh berbagai pihak dapat mendorong terjadi tindakan balas dendam dari korban dan keluarganya terhadap pelaku tindak pidana dan keluarganya. ${ }^{48}$ Sejalan dengan perkembangan hukum pidana modern, perdamaian yang dilakukan antara korban

Badan Pembinaan Hukum Nasional. Op Cit. hlm.i

45 Mokhammad Najih. Politik Hukum Pidana: Kosep Peembaharuan Hukum Pidana Dalam Cita Negara Hukum. (Malang: Stara Press, 2014). hlm. 39

46 Kebijakan perumusan sistem pemidanaan yang berorientasi pada korban secara in concreto dalam hukum positif saat ini tidak ada dalam ketentuan induk KUHP/WvS, namun hanya ada pada sebagian kecil ketentuan perundang-undangan di luarnya, sedangkan pada sebagian besarnya masih berorientasi pada pelaku tindak pidana. Terjadi kebijakan perumusan sistem pemidanaan yang berorientasi pada korban dalam ketentuan perundang-undangan di luar KUHP/WvS merupakan bentuk kebijakan murni yang tidak terjalin secara sistem dengan induknya. Eko Soponyono. Kebijakan Perumusan Sistem Pemidanaan Yang Berorientasi Pada Korban. Jurnal Masalah-Masalah Hukum, Jilid 41 Nomor 1 Jnauari 2012. hlm.40

47 Alef Musyahadah R. Op Cit. hlm. 135

48 Natangsa Surbakti. Op Cit. hlm. 203 
dengan pelaku tindak pidana dengan diikuti ganti rugi atas terjadinya tindak pidana perlu dikembangkan kebijakan pengaturannya ${ }^{49}$ dalam pembaruan hukum pidana nasional. RUU KUHP (tahun 2015) telah mengakomodasi bahwa pengaruh tindak pidana terhadap korban atau keluarganya dan pemaafan dari korban dan/atau keluarganya menjadi dasar pertimbangan dalam pemidanaan (Pasal 56 ayat (1) huruf I, j dan k). Pemberian ganti kerugian yang layak atau perbaikan kerusakan secara sukarela sebagai akibat tindak pidana yang dilakukan menjadi faktor peringanan pidana (Pasal 139). Bahkan dimungkinkannya hakim memberi maaf/pengampunan ("rechterlijk pardon") tanpa menjatuhkan pidana/tindakan apapun terhadap terdakwa, sekalipun telah terbukti adanya tindak pidana dan kesalahan. ${ }^{50}$

Pada rumusan yang ada dalam pembaruan hukum pidana nasional tersebut di atas, hakim diberikan ruang untuk menilai pemulihan kerugian dan pemaafan korban terhadap pelaku dalam lingkup perdamaian sesuai nilai Pancasila yaitu permusyawaratan dalam kebijaksanaan pemidanaan. Muladi menjelaskan bahwa ${ }^{51}$ hakikat tujuan pemidanaan dalam konteks Pancasila, yang pertama-tama harus dihayati adalah pendekatan multidimensional yang bersifat mendasar terhadap dampak tindak pidana. Dengan demikian tujuan pemidanaan adalah untuk memperbaiki kerusakan baik yang bersifat individual, maupun yang bersifat sosial (individual and social damages) yang diakibatkan oleh tindak pidana. Dalam kerangka ini, maka tujuan pemidanaan harus berorientasi pada pandangan yang integratif, yang terdiri dari seperangkat tujuan pemidanaan yang harus dipenuhi, dengan catatan bahwa tujuan manakah yang merupakan titik berat sifatnya kasuistis. Dalam tujuan pemidanaan pula tercakup tujuan memelihara solidaritas masyarakat. Pemidanaan harus diarahkan untuk memelihara dan mempertahankan kesatuan masyarakat (to maintain social cohasion intact).

Berkaitan dengan konteks perdamaian berdasarkan permusyawaratan dan kebijaksanaan dalam tujuan pemidanaan di atas maka sudah seharusnya bahwa tidak saja menjadi alasan peringanan pidana saja, tetapi dapat berupa penghapusan pemidanaan bilamana telah terpulihkannya kerugian korban dan akibat terganggunya sosial dari tindak pidana telah pula diharmonisasikan kembali. Dengan demikian pembaruan hukum pidana nasional telah memberikan penegasan akan sebuah upaya refilosofi pemidanaan dari retributive justice menuju restorative justice. Orientasi penghukuman sejauh mungkin dapat bermanfaat bagi para pihak (dalam hal ini Korban, Pelaku dan masyarakat) guna pemulihan konflik di masa yang akan datang. Oleh karenanya output dari proses peradilan ini adalah tetap berlandaskan pada penyelesaian konflik dan pemulihan hubungan antar pihak. Dengan demikian tindak pidana dipersepsikan sebagai pelanggaran terhadap hak-hak individu (korban) oleh individu yang lain (Pelaku) dalam masyarakat, sehingga penyelesaiannya pun diorientasikan pada pemulihan hubungan.

\section{Penutup}

Perdamaian merupakan cara penyelesaian sengketa dan konflik yang terbaik dalam kultur

\footnotetext{
49 Alef Musyahadah R. Op Cit. hlm.143-144

50 Naskah Akademik RUU KUHP 2015, hlm.120

51 Eko Soponyono, Op Cit. hlm.30
} 
bangsa Indonesia. Lembaga perdamaian dalam sistem hukum positif sudah diakui eksistensinya dalam penyelesaian perkara perdata, baik melalui arbitrase maupun mediasi. Dalam penyelesaian perkara pidana, perdamaian yang melibatkan korban, pelaku dan masyarakat masih terbatas dan dilaksanakan di luar pengadilan. Khusus untuk peradilan pidana anak, sudah mengakomodasi perdamaian melalui lembaga diversi yang berporos pada keadilan restoratif. Terkecuali perkara pidana anak, penerapan perdamaian dalam sidang pengadilan tidak dapat menghapuskan pemidanaan dari hakim. Perdamaian antar pelaku dan korban dengan diikuti penggantian kerugian dan pemaafan hanya berfungsi meringankan pemidanaan terhadap pelaku. Di luar kelaziman, terdapat putusan Pengadilan Negeri Jakarta Utara-Timur Nomor 46/Pid/78/ UT/Wanita yang memberikan pelepasan dari tuntutan hukuman atas dasar telah terjadi perdamaian. Pada dasarnya perbuatan terdakwa telah terbukti dan memenuhi unsur pasal yang didakwakan Jaksa Penuntut Umum, tetapi tidak dapat diputus pemidanaannya karena dipandang bukan merupakan tindak pidana. Sifat melawan hukumnya telah dihilangkan dengan pertimbangan bahwa dengan adanya perdamaian maka kepincangan sosial akibat tindak pidana sudah terpulihkan. Kaidah hukum dari putusan ini yaitu perdamaian diantara pelaku dan korban dapat dijadikan dasar alasan penghapusan pemidanaan ternyata diikuti oleh putusan pengadilan lainnya sehingga dikualifikasi sebagai yurisprudensi.

Sejatinya yurisprudensi ini menampakkan tentang urgensi pergeseran pemahaman tentang kejahatan dan tujuan pemidanaan terhadap pelakunya menuju pada keadilan restoratif. Sebagai salah satu sumber hukum formal, yurisprudensi ini layak diakomodasi dalam pembaruan pemidanaan dalam RUU KUHP. Secara tepat konsep filsafat pemidanaan dalam Rancangan KUHP (Tahun 2015) mengakomodasi pemidanaan sebagai sarana menyelesaiakan konflik yang ditimbulkan oleh tindak pidana, memulihkan keseimbangan dan mendatangkan rasa damai dalam masyarakat (Pasal 55 ayat 1 huruf c). Pemberian ganti kerugian yang layak atau perbaikan kerusakan secara sukarela sebagai akibat tindak pidana yang dilakukan menjadi faktor peringanan pidana (Pasal 139). Bahkan dimungkinkannya hakim memberi maaf/pengampunan ("rechterlijk pardon") tanpa menjatuhkan pidana/tindakan apapun terhadap terdakwa, sekalipun telah terbukti adanya tindak pidana dan kesalahan. Orientasi penghukuman sejauh mungkin dapat bermanfaat bagi para pihak (dalam hal ini Korban, Pelaku dan masyarakat) guna pemulihan konflik di masa yang akan datang. Oleh karenanya output dari proses peradilan ini adalah tetap berlandaskan pada penyelesaian konflik dan pemulihan hubungan antar pihak. Dalam konteks inilah dikehendaki sebuah upaya refilosofi penghapusan pemidanaan berdasarkan perdamaian untuk mewujudkan keadilan sangat urgen diakomodasi dalam pembaruan hukum pidana nasional di masa yang akan datang.

\section{Daftar Pustaka}

\section{Buku}

Alfitra, Hapusnya Hak Menuntut Menjalankan Pidana, (Depok: Raih Asa Sukses, 2012)

Ali, M. Hatta, Peradilan Sederhana, Cepat \& Biaya Ringan Menuju Keadilan Restoratif,(Bandung: Alumni, 2012)

Badan Pembinaan Hukum Nasional, Naskah Akademik Rancangan Undang-Undang Tentang Kitab Undang-Undang Hukum Pidana (KUHP), 
(Jakarta: Kementerian Hukum dan Hak Asasi Manusia, 2015)

Harahap, M Yahya, Pembahasan Permasalahan dan Penerapan KUHAP: Pemeriksaan Sidang Pengadilan, Banding, Kasasi, dan Peninjauan Kembali, (Jakarta: Sinar Grafika, 2009)

Hiariej, Eddy O.S, Prinsip-Prinsip Hukum Pidana, (Yogyakarta: Cahaya Atmaka Pustaka, 2014)

Huijbers, Theo, Filsafat Hukum dalam Lintasan Sejarah, (Yogyakarta: Kanisius, 1982)

Irianto, Sulistyowati dan Shidarta, Metode Penelitian Hukum (Konstelasi dan Refleksi), (Jakarta: Yayasan Pustaka Obor Indonesia. 2011)

Kamil, Ahmad, Filsafat Kebebasan Hakim, (Jakarta: Kencana Prenada Media, 2012)

Marzuki, Peter Mahmud, Penelitian Hukum, (Jakarta: Kencana, 2014)

Mulyadi, Lilik, Hukum Acara Pidana Indonesia: Suatu Tinjauan Khusus Terhadap Surat Dakwaan, Eksepsi, dan Putusan Peradilan, (Bandung: Citra Aditya Bhakti, 2012)

Mulyadi, Lilik, Implementasi Mediasi Penal Sebagai Perwujudan Nilai-Nilai Pancasila Guna Mendukung Supremasi Hukum Dalam Rangka Pembangunan Hukum Nasional, (Yogyakarta: Genta Publishing, 2016)

Najih, Mokhammad, Politik Hukum Pidana: Konsep Pembaharuan Hukum Pidana Dalam Cita Negara Hukum, (Malang: Stara Press, 2014)

Pangaribuan, Luhut M.P. Hukum Acara Pidana: Surat Resmi Advokat di Pengadilan, (Jakarta: Papas Sinar Sinanti, 2014)

Panggabean, H.P. Penerapan Teori Hukum Dalam Sistem Peradilan Indonesia, (Bandung: Alumni, 2014)

Rusianto,Agus, TindakPidana\& Pertanggungjawaban Pidana: Tinjauan Kritis Melalui Konsistensi antara Asas, Teori, dan Penerapannya, (Jakarta: Kencana, 2016)

Sudirman, Antonius, Hati Nurani Hakim dan Putusannya: Suatu Pendekatan dari Perspektif IImu Hukum Perilaku (Bahavioral Jurisprudence) Kasus Hakim Bismar Siregar, (Bandung: Citra Aditya Bakti, 2007)

Suhariyanto, Budi, Perlindungan Hukum terhadap Korban Kejahatan Dalam Sistem Peradilan Pidana Ditinjau Dari Perspektif Restoratif Justice. (Jakarta: Pusat Penelitian dan Pengembangan Mahkamah Agung, 2013)

Sukadana, I Made, Mediasi Peradilan: Mediasi dalam Sistem Peradilan Perdata Indonesia dalam Rangka Mewujudkan Proses Peradilan yang Sederhana, Cepat, dan Biaya Ringan, (Jakarta: Prestasi Pustaka, 2012)

Sunarso, Siswanto. Viktimologi Dalam Sistem Peradilan Pidana. (Jakarta: Sinar Grafika, 2012).

Surbakti, Natangsa. Peradilan Restoratif: Dalam Bingkai Empiri, Teori dan Kebijakan. (Yogyakarta: Genta Publishing, 2015)

Thaib, Hasballah, Perdamaian Adalah Panglima Dari Semua Hukum. Dalam Pendastaren Tarigan dan Arif (Ed). Spirit Hukum: Dedikasikan Untuk Purna Bakti 70 Tahun Prof. Hj.Rehgena Purba.SH.,MH, (Jakarta: Rajawali Pers, 2012)

Utrecht, E., Hukum Pidana I: Rangkaian Sari Kuliah, (Jakarta: Penerbitan Universitas, Tanpa Tahun)

Yuherawan, Deni Setyo Bagus, Dekonstruksi asas Legalitas Hukum Pidana: Sejarah Asas Legalitas dan Gagasan Peembaharuan Filosofi Hukum Pidana, (Malang: Setara Press, 2014)

Zulva, Eva Achjani, Gugurnya Hak Menuntut: Dasar Penghapus, Peringan, dan Pemberat Pidana, (Bogor: Ghalia Indonesia, 2010)

Zulfa, Eva Achjani, Pergeseran Paradigma Pemidanaan, (Bandung: Lubuk Agung, 2011)

\section{Makalah/Artikel/Laporan/Hasil Penelitian}

Musyahadah, Alef R., Kedudukan Perdamaian Antara Korban Dengan Pelaku Tindak Pidana Dalam Sistem Pemidanaan. Tesis, (Semarang: Program Pasca Sarjana Universitas Diponegoro, 2005)

Rahayu, Sri, "Diversi Sebagai Alternatif Penyelesaian Perkara Tindak Pidana Yang Dilakukan Anak Dalam Perspektif Sistem Peradilan Pidana Anak". Jurnal Ilmu Hukum Tahun (2015)

Soponyono, Eko, "Kebijakan Perumusan Sistem Pemidanaan Yang Berorientasi Pada Korban". Jurnal Masalah-Masalah Hukum, Jilid 41 Nomor 1 Janauari (2012)

Suhariyanto, Budi, "Eksistensi Pembentukan Hukum Oleh Hakim Dalam Dinamika Politik Legislasi Di Indonesia", Jurnal Rechtsvinding Volume 4 Nomor 3 Desember (2015)

Surya, Faizal Adi, "Tinjauan Mediasi Penal Dalam Perspektif Hukum Adat dan Hukum Islam". Jurnal Jurisprudence, Volume 5 Nomor 2 Sseptember (2015)

Yunus, Yutirsa, "Analisis Konsep Restoratif Justice Melalui Sistem Diversi Dalam Sistem Peradilan Pidana Anak Di Indonesia". Jurnal Rechtsvinding Volume 2 Nomor 2 Agustus (2013) 
"Halaman ini dikosongkan" 